\title{
Condylar fracture in a paediatric patient undergoing conservative and functional treatment: Case report
}

\author{
Tratamento conservador e funcional de fratura condilar em paciente pediátrico: Relato de caso \\ Tratamiento conservador y funcional de la fractura condilar en un paciente pediátrico: Reporte de
}

un caso

Received: 03/29/2021 | Reviewed: 04/09/2021 | Accept: 04/13/2021 | Published: 04/24/2021

Guilherme Borsato Gomes

ORCID: https://orcid.org/0000-0002-3973-3362

State University of Londrina, Brazil

E-mail: guilherme.brosato@uel.br

Leticia Sassaki Correia

ORCID: https://orcid.org/0000-0002-1665-1698 State University of Londrina, Brazil

E-mail: leticia.sassaki@uel.br

Fernanda Schimidt de Freitas

ORCID: https://orcid.org/0000-0003-4488-4568

State University of Londrina, Brazil

E-mail: nanda.de.freitas@hotmail.com

Vinícius Almeida Carvalho

ORCID: https://orcid.org/0000-0002-5393-227X

State University of Londrina, Brazil

E-mail: viniacforpusp@gmail.com

Cecília Luiz Pereira Stabile

ORCID: https://orcid.org/0000-0003-1188-2769 State University of Londrina, Brazil E-mail: ceciliastabile@uel.br

Glaykon Alex Vitti Stabile

ORCID: https://orcid.org/0000-0001-5878-9575 State University of Londrina, Brazil E-mail: glaykon@uel.br

\begin{abstract}
Trauma to the jaw can lead to fracture of the mandibular condyle. Prevalence in children is low and treatment should focus on possible long-term effects on facial bone and soft tissue growth. Trauma can result in dysfunction, facial asymmetry, mandibular retraction, dysfunction and stiffness of the temporomandibular joint. Clinical examination and imaging tests are essential to obtain an accurate diagnosis and an effective treatment to avoid possible complications. Treatment can be surgical or non-surgical, but non-surgical treatment is the method of choice in most cases. The aim of this study is to report a case of mandibular condylar fracture in a pediatric patient who underwent conservative and functional care who, with adequate monitoring by the Maxillofacial Surgery and Traumatology team and family, showed complete remodeling of the fractured bone and total recovery of the dental occlusion. Treatment in pediatric patients through conservative management allows an adequate range of mandibular movement and remodeling at the fracture site, but patient and family adherence to treatment is very important to obtain good results. Keywords: Dentistry; Rehabilitation; Temporomandibular joint; Child; Case report.
\end{abstract}

\section{Resumo}

$\mathrm{O}$ trauma na mandíbula pode levar à fratura do côndilo mandibular. A prevalência em crianças é baixa e o tratamento deve se concentrar nos possíveis efeitos de longo prazo no osso facial e no crescimento dos tecidos moles. O trauma pode resultar em disfunção, assimetria facial, retração mandibular, disfunção e rigidez da articulação temporomandibular. O exame clínico e os exames de imagem são essenciais para obter um diagnóstico preciso e um tratamento eficaz para evitar possíveis complicações. O tratamento pode ser cirúrgico ou não cirúrgico, mas o tratamento não cirúrgico é o método de escolha na maioria dos casos. O objetivo deste estudo é relatar um caso de fratura de côndilo mandibular em paciente pediátrico submetido a cuidados conservadores e funcionais, que com acompanhamento adequado da equipe de Cirurgia e Traumatologia Bucomaxilofacial e familiares, apresentou remodelação completa do osso fraturado e recuperação total da oclusão dentária. O tratamento em pacientes pediátricos através do manejo conservador permite uma amplitude de movimento mandibular adequada e 
remodelação no local da fratura, mas a adesão do paciente e de sua família ao tratamento é muito importante para a obtenção de bons resultados.

Palavras-chave: Odontologia; Reabilitação; Articulação temporomandibular; Criança; Relato de caso.

\begin{abstract}
Resumen
El traumatismo de la mandíbula puede provocar la fractura del cóndilo mandibular. La prevalencia en los niños es baja y el tratamiento debe centrarse en los posibles efectos a largo plazo sobre el crecimiento de los huesos faciales y los tejidos blandos. El trauma puede resultar en disfunción, asimetría facial, retracción mandibular, disfunción y rigidez de la articulación temporomandibular. La exploración clínica y las pruebas de imagen son fundamentales para obtener un diagnóstico certero y un tratamiento eficaz para evitar posibles complicaciones. El tratamiento puede ser quirúrgico o no quirúrgico, pero el tratamiento no quirúrgico es el método de elección en la mayoría de los casos. El objetivo de este estudio es reportar un caso de fractura condilar mandibular en un paciente pediátrico que fue sometido a cuidados conservadores y funcionales que, con un adecuado seguimiento por parte del equipo de Cirugía y Traumatología Buccomaxilofacial y familiares, mostró remodelado completo del hueso fracturado y recuperación total de la oclusión dental. El tratamiento en pacientes pediátricos mediante manejo conservador permite un rango adecuado de movimiento mandibular y remodelado en el sitio de la fractura, pero la adherencia del paciente y la familia al tratamiento es muy importante para obtener buenos resultados.
\end{abstract}

Palabras clave: Odontología; Rehabilitación; Articulación temporomandibular; Niño; Reporte de un caso.

\title{
1. Introduction
}

Facial fractures in paediatric patients are unusual. Due to ongoing facial growth in children, facial trauma when inappropriately diagnosed or treated can result in deformities and asymmetry (Fonseca, Walker, Barber, Powers \& Frost, 2015)

There are three main types of treatment: surgery with open reduction and internal fixation; and conservative treatment, with or without maxillomandibular fixation (MMF). Conservative management is known to be non-invasive and minimally challenging, avoiding the potential risks of open surgical procedures and providing as minimal deleterious effects on the temporomandibular joint as possible (Ghasemzadeh, Mundinger, Swanson, Utria \& Amir, 2015).

This type of treatment is considered to be the standard, allows early intra-articular recovery and eliminates additional intracapsular trauma that may cause future limitations due to the potential for bone remodelling at condyle level in paediatric patients (Ghasemzadeh et al., 2015).

The purpose of this article is to report a case of a mandibular condyle fracture in a paediatric patient undergoing conservative and functional care which, with proper monitoring of the OMS team and family members, presented complete remodeling of the fractured bone and total dental occlusion recovery.

\section{Methodology}

This article consists of a descriptive case study. The work was not submitted to the ethics and research committee, as it is a case report, whose procedure to be performed was not experimental. The patient's legal guardian has a signature on the free and informed consent form about all procedures performed during the treatment and regarding the use of image. This case was managed by the Oral and Maxillofacial Surgery team at the Northern Regional Hospital of Paraná (State University of Londrina) and the patient was followed-up for two years since the trauma in 2017.

\section{Case Report}

A seven-year-old male patient, victim of a cycling accident, sought the Oral and Maxillofacial Surgery department reporting a direct impact on the chin and complaining of facial pain. On physical examination he presented a small chin laceration, a deviation of the mandible to the right side (Figure 1) with a 33mm mouth opening (Figure 2). He felt pain on the right preauricular region and the right condyle wasn't palpable. Dental occlusion was stable and the upper right central incisor was fractured (Figure 3). 
Research, Society and Development, v. 10, n. 4, e58510414429, 2021

(CC BY 4.0) | ISSN 2525-3409 | DOI: http://dx.doi.org/10.33448/rsd-v10i4.14429

Suspecting of a right condyle fracture, a computed tomography (CT) was requested and the images (figure 4) showed a fracture of the right mandibular condyle with significant displacement to the medial.

Figure 1. Limitation of mouth opening with deviation to the right side.

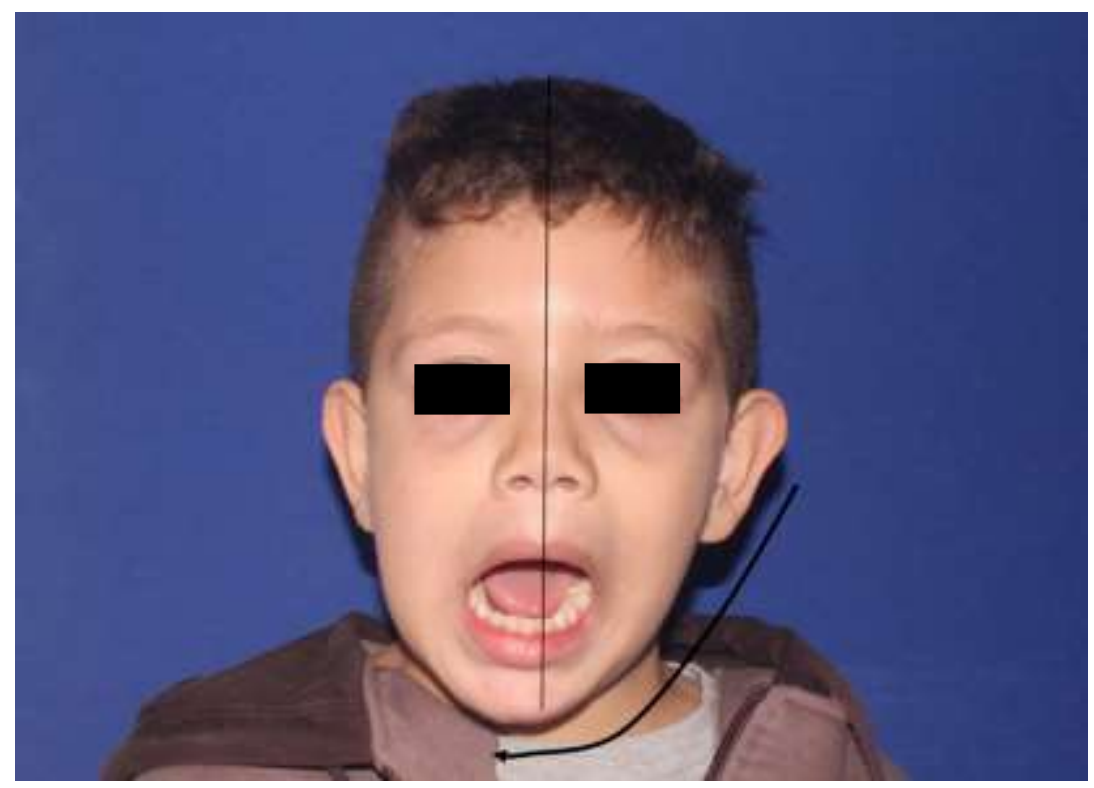

Source: Authors.

Figure 2. Mouth opening of $33 \mathrm{~mm}$.

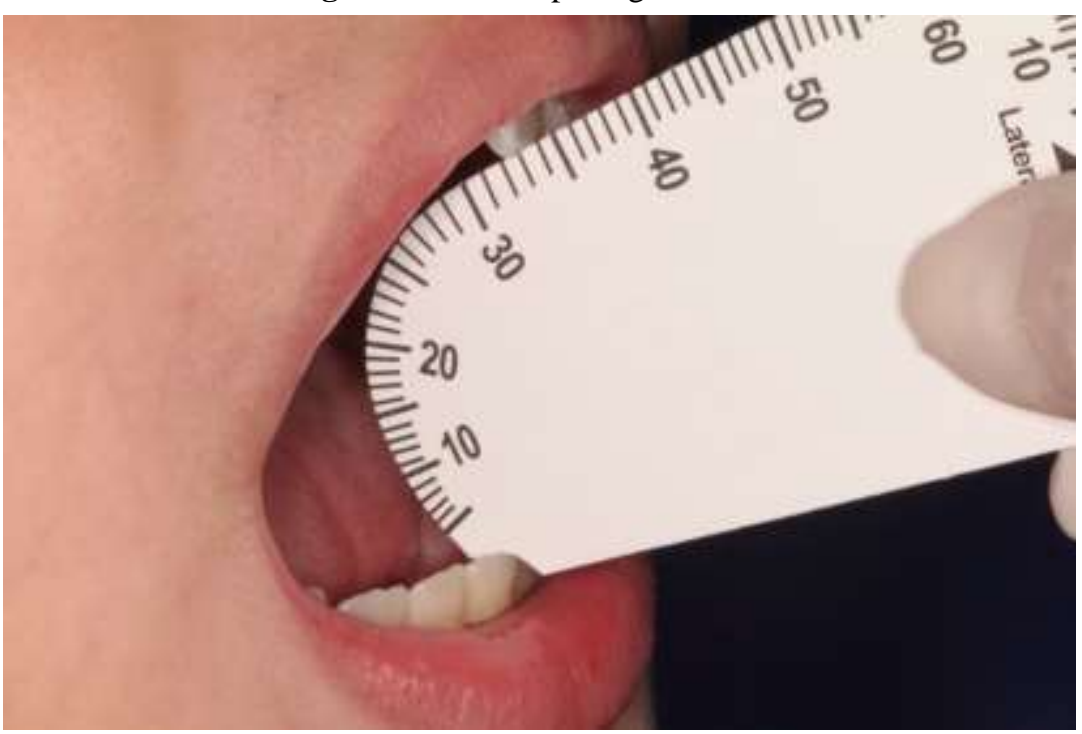

Source: Authors. 
Figure 3. Stable occlusion with coronary fracture of upper right central incisor.

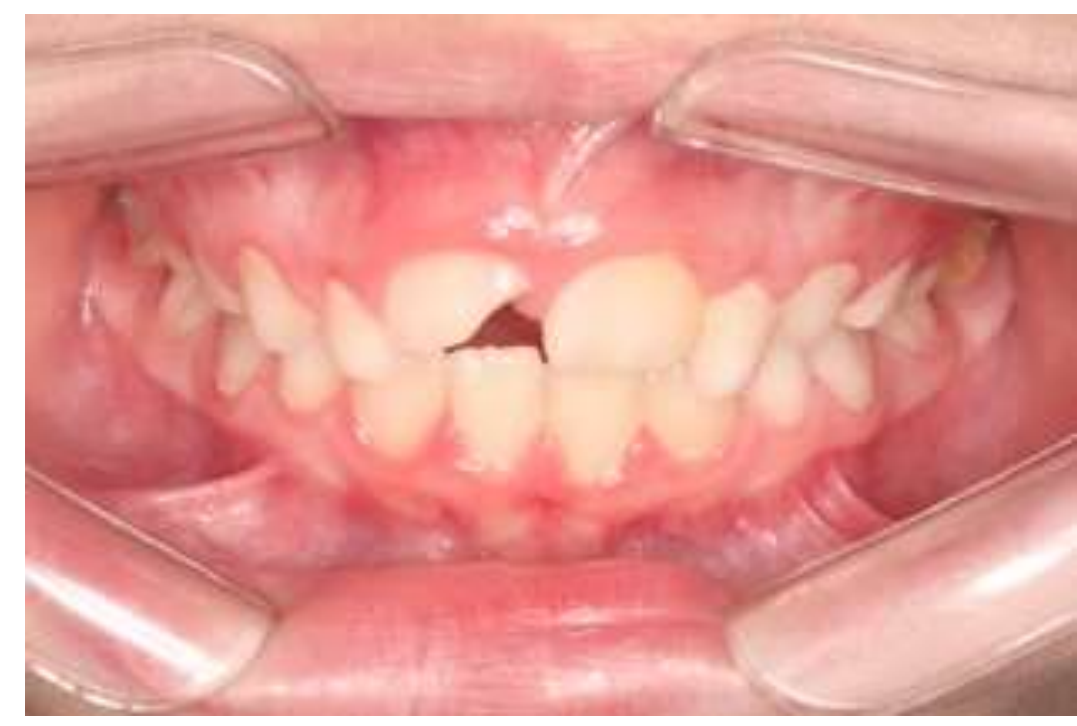

Source: Authors.

Figure 4. Coronal CT scan showing fracture of the right mandibular condyle with displacement to medial.

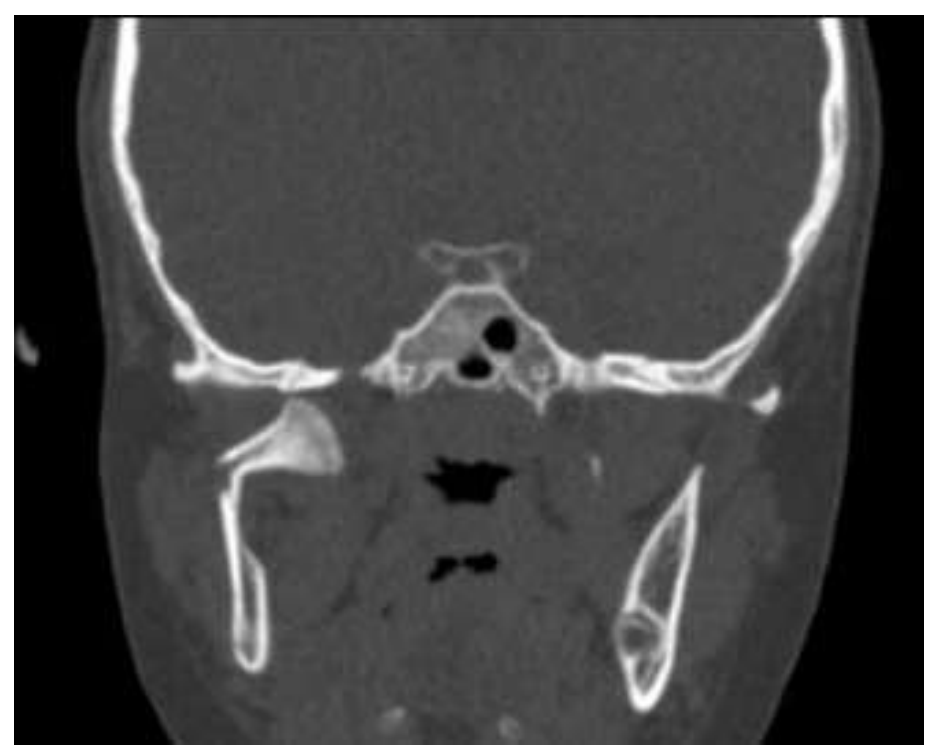

Source: Authors.

Taking into account the patient's age and the characteristics of the fracture, a conservative treatment plan was drawn up with functional physical therapy and without MMF, aiming to improve mobilization and early return to function. Treatment began immediately after the trauma with analgesics and non-steroidal anti-inflammatory drugs, warm compresses in the preauricular region, a soft diet and physiotherapy exercises for mouth opening and mandibular excursion.

The patient was followed up closely, and 40 days after trauma he denied pain but still had a mandibular deviation to the right and a small improvement in the mouth opening $(35 \mathrm{~mm})$. After one year, there was a complete reestablishment, with $44 \mathrm{~mm}$ mouth opening (Figure 5) without mandibular deviation (Figure 6), stable and satisfactory jaw movement and occlusion. CT scans showed total remodelling of the right condyle inside the articular fossa, changes in condyle anatomy and an imbalance in the length of the condyle neck in comparison to the opposite side (Figures 7 and 8). 
Research, Society and Development, v. 10, n. 4, e58510414429, 2021

(CC BY 4.0) | ISSN 2525-3409 | DOI: http://dx.doi.org/10.33448/rsd-v10i4.14429

Figure 5. Mouth opening of $44 \mathrm{~mm}$.

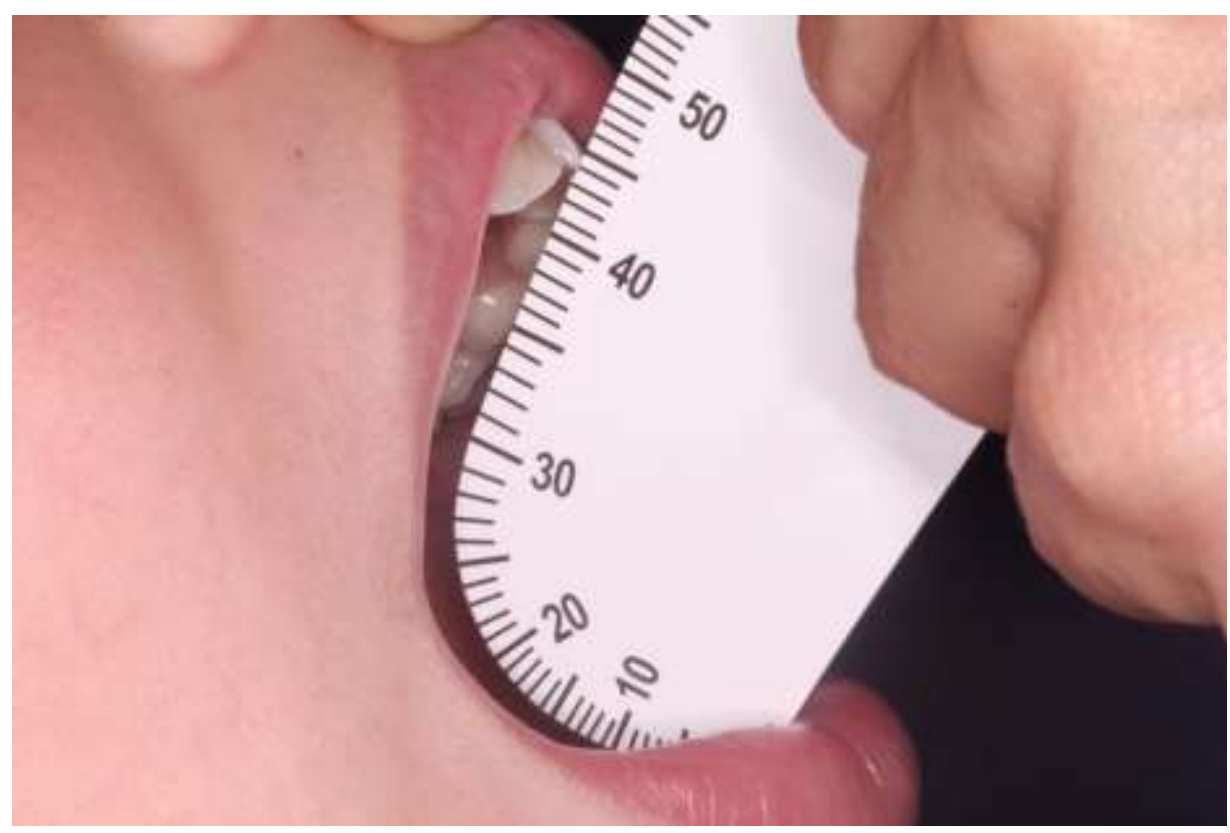

Source: Authors.

Figure 6. Mouth opening without mandibular deviation.

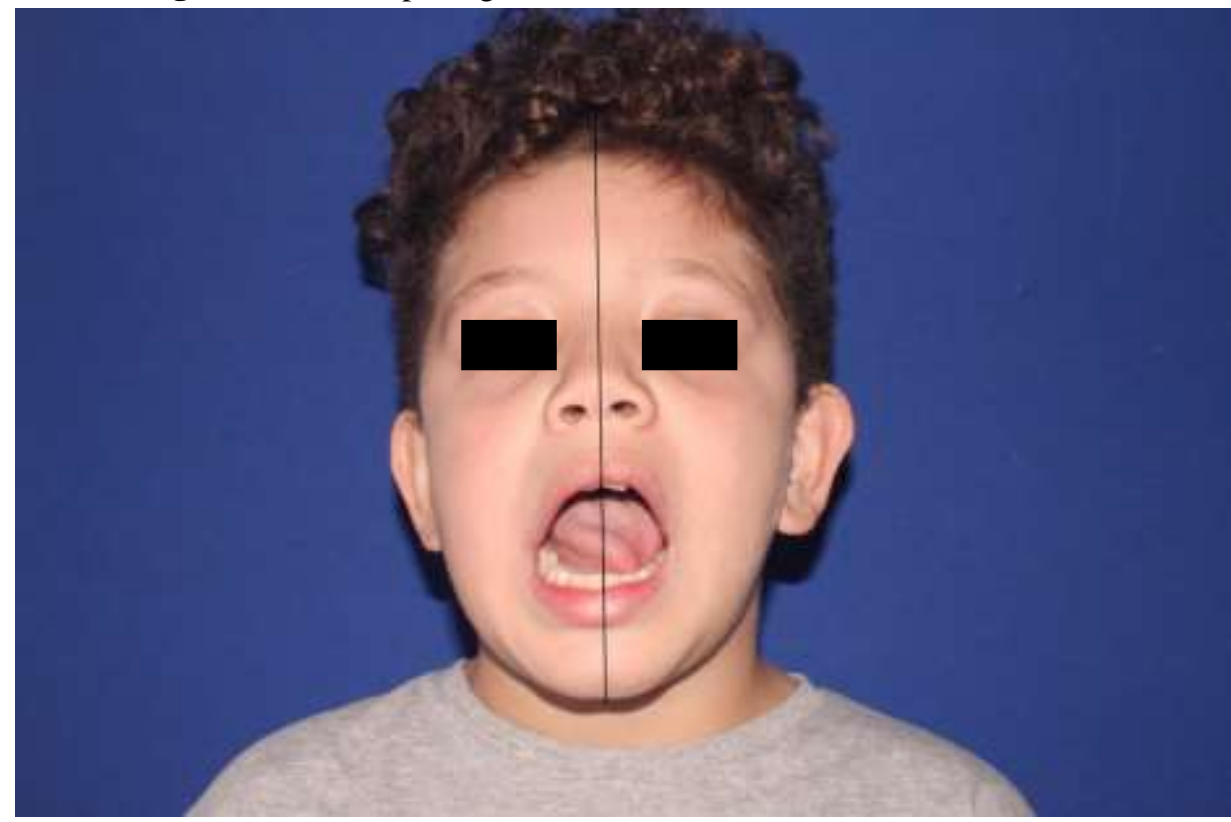

Source: Authors. 
Figures 7 and 8. Sagittal CT showing right condyle remodelling with remaining discrepancy in condyle neck length.

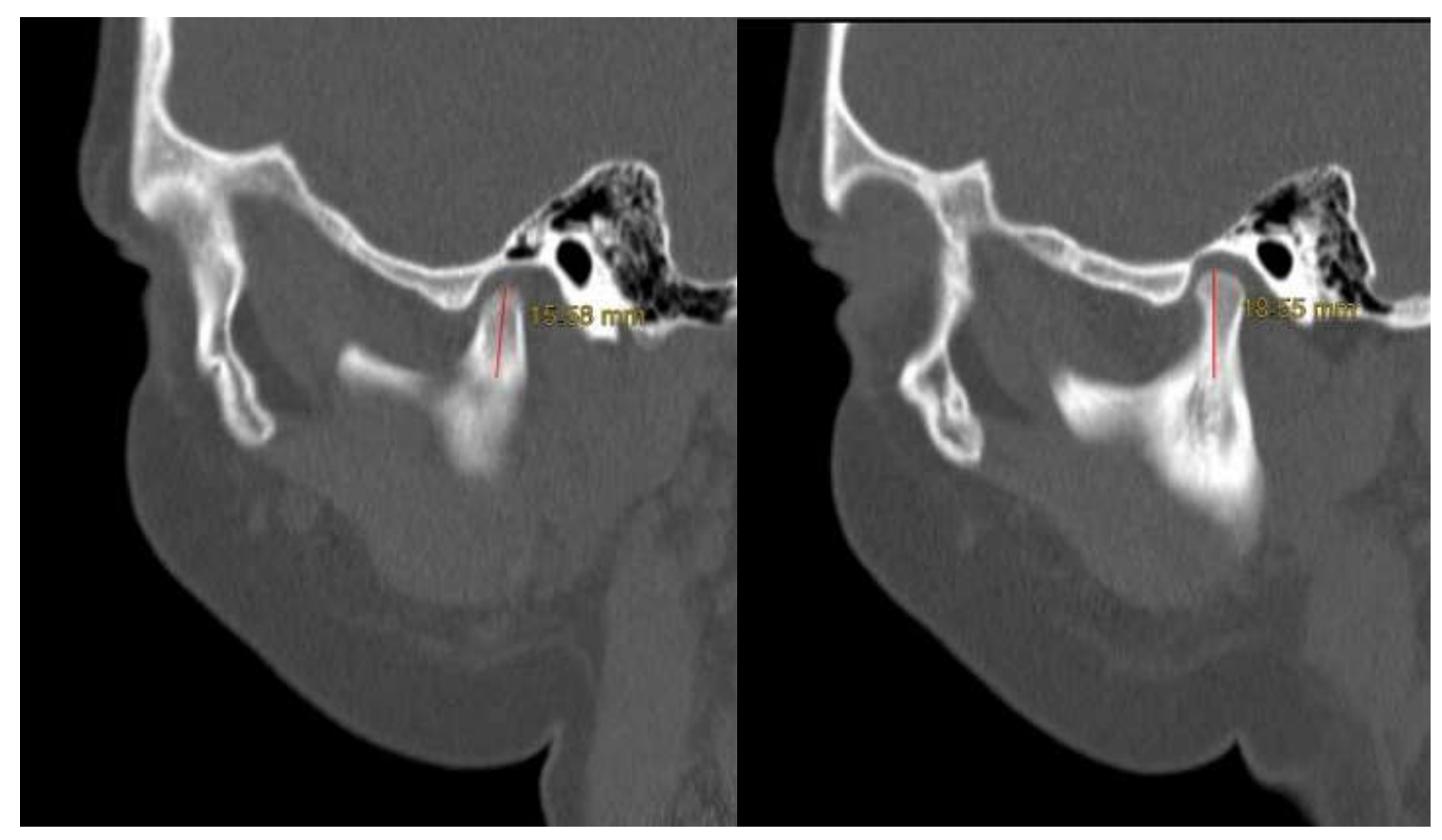

Source: Authors.

\section{Discussion}

The rate of facial fractures in paediatric patients is relatively low (15\%), mainly due to anatomical factors that protect the facial skeleton ${ }^{3}$. Among these, the following stand out: the greater proportion of the skull bones compared to the facial bones, greater bone elasticity (thin cortical and thick medulla), less pneumatized paranasal sinuses, unerupted teeth and a rich layer of fat capable of attenuating the forces of impact (Posnick, Wells \& Pron, 1993; Morano, Sampaio, Freitas, Alonso \& Ferreira, 1998).

Facial fractures in children display unique features that can make proper diagnosis difficult. Clinical and radiological examinations are quite daunting, especially in younger children, as palpation of the facial bones is less effective than in adult patients. In conventional radiography, on the other hand, given the small pneumatization of the paranasal sinuses or their absence, it is challenging to visualize facial fractures (Alonso et al., 1998).

The most frequent aetiologies of facial fractures in children are: fall from height (23\%), being run over (18\%), bicycle fall (13\%), vehicle collision (13\%) and fall from one's own height (12\%), among other causes (10\%) (Posnick et al., 1993). Their anatomical location in the jaw varies according to age, but overall condylar fractures, unilateral or bilateral, are one of the most common in children under 12 years old (27,9\%) (Posnick et al., 1993; Reid, 2020).

Treatment of condylar fractures in children should be based on basic concepts, such as reestablishment of a satisfactory occlusion, adequate masticatory function with extrinsic movements, wide and free mouth opening and maintenance of facial symmetry (Menon, Kumar, Archana, Nath \& Shivakotee, 2020). Three treatment modalities can be applied in children: shortterm immobilization with MMF, surgical intervention with open reduction and internal fixation and non-surgical intervention applying physiotherapy associated with analgesia (Rozeboom, Klumpert, Koutris, Dubois, Speksnijder, Lobbezoo \& Lange, 2018; Cassi, Magnifico, Di Blasio, Gandolfini \& Di Blasio, 2017).

Growing patients have rapid bone healing, achieving adequate occlusal stability within two to three weeks. Therefore, in fractures with occlusal repercussions, an immediate MMF can be used for two weeks for symptom relief, followed by progress into a liquid/pasty diet and passive and active physical therapy with exercises to improve range of motion (Cassi et al., 2017). However, MMF can be very difficult to tolerate, especially by younger patients (Aguiar, Moraes, Araújo \& Zevallos, 2019). 
Open surgery and internal fixation of fractures can contribute to certain complications, one of which is asymmetry in the development of the mandibular ramus on the affected side, similar to that which occurs after resorption and condyle neoformation (Aguiar et al., 2019). Future perspectives for surgical treatment include minimally invasive endoscopic surgery, but this technique is not available in most hospitals, requires specific training and equipment and has a very steep learning curve. Bioresorbable fixation materials have also been discussed as a promising alternative for fracture treatment in children, however, the high cost of these materials makes them difficult to obtain in most developing countries such as Brazil (Pedroletti, Johnson \& McCain, 2010). Thus, the recommended treatment for condylar fractures in children has been non-surgical through the restoration of normal occlusion - with or without MMF - followed by physical therapy (Aguiar et al., 2019).

\section{Final Considerations}

Condylar fracture treatment in paediatric patients through conservative management with early mobilization, occlusion control and functional therapy is a safe, affordable, non-invasive treatment with a very favourable prognosis that allows for adequate range of motion and remodelling at the fracture site. However, the patient's and their family's compliance to treatment is very important to achieve good results.

\section{References}

Aguiar, P. L., Moraes, B. C., Araújo, G. M., \& Zevallos, E. A. A. (2019). Tratamento conservador de fratura de côndilo mandibular em paciente pediátrico: relato de caso. Revista de saúde da aeronáutica, 2, 29-33.

Cassi, D., Magnifico, M., Di Blasio, C., Gandolfini, M., \& Di Blasio, A. (2017). Functional treatment of a child with extracapsular mandibular fracture. Case reports in dentistry, 2017.

Fonseca, R. J., Walker, R. J., Barber, H. D., Powers, M. P., \& Frost, D. E. (2015). Trauma bucomaxilofacial. Elsevier Brasil.

Ghasemzadeh, A., Mundinger, G. S., Swanson, E. W., Utria, A. F., \& Dorafshar, A. H. (2015). Treatment of pediatric condylar fractures: a 20-year experience. Plastic and reconstructive surgery, 136(6), 1279.

Menon, S., Kumar, V., Archana, S., Nath, P., \& Shivakotee, S. (2019). A Retrospective Study of Condylar Fracture Management in a Tertiary Care HospitalA 10-Year Experience. Journal of Maxillofacial and Oral Surgery, 1-7.

Morano, F. G., Sampaio, M. M. C., Freitas, R. D. S., Alonso, N., \& Ferreira, M. C. (1998). Análise de 126 fraturas de face em crianças menores de 12 anos. Revista do Colégio Brasileiro de Cirurgiões, 25(3), 201-204.

Pedroletti, F., Johnson, B. S., \& McCain, J. P. (2010). Endoscopic techniques in oral and maxillofacial surgery. Oral and Maxillofacial Surgery Clinics, 22(1), $169-182$.

Posnick, J. C., Wells, M., \& Pron, G. E. (1993). Pediatric facial farctures: Evolving patterns of treatment. Journal of oral and maxillofacial surgery, 51(8), 836844.

Reid, R. R. (2020). Facial Trauma Surgery: From Primary Repair to Reconstruction. Plastic and Reconstructive Surgery, $145(4), 1104$.

Rozeboom, A. V. J., Klumpert, L. T., Koutris, M., Dubois, L., Speksnijder, C. M., Lobbezoo, F., \& de Lange, J. (2018). Clinical outcomes in the treatment of unilateral condylar fractures: a cross-sectional study. International journal of oral and maxillofacial surgery, 47(9), $1132-1137$. 